\title{
Statutory Union Recognition Provisions as Stimulants to Employer Anti-Unionism in Three Anglo-Saxon Countries
}

\section{Introduction}

In periods of union weakness, largely resultant from employer opposition, unions have campaigned for, and often achieved, the creation of legal or regulatory provisions to facilitate the gaining of union recognition (UR). In this way, unions have sought to shortcircuit their industrial or economic weakness vis-à-vis employers by campaigning in the political arena to gain state-supported provisions to compel employers to negotiate with them. However, such provisions for gaining UR in Britain, Eire, and the United States (US) are argued to be a major factor in helping to stimulate employer opposition to UR campaigns, transforming latent employer opposition to labour unionism into active opposition, and further deepening existing employer anti-unionism (EA-U) towards UR campaigns. So, for non-union employers, the creation of statutory or state-supported union recognition provisions (SURPs) represents a transmutation in the status of the 'union threat' from hypothetical into potential and potential into actual. Employers, then, feel compelled to take preventative, corrective and retaliatory actions. Such actions have been broadly successful in pushing back and extinguishing or defeating UR campaigns. This phenomenon has two further important facets in the three countries at hand. First, the extent of employer opposition and its effectiveness is argued to be largely attributable to both the weakly supportive nature of the UR laws and wider public policy vis-à-vis labour unionism. Second, the insertion of weak UR provisions into national systems characterised by minimal state intervention in industrial relations (compared to a number of continental European countries) further strengthens 
employers' ability to frustrate union attempts to gain UR using SURPs. Herein lies a paradox. In periods of union weakness, unions are arguably in greater need of statutory and governmental support to help redress the accentuated power imbalance vis-à-vis employers, but this stimulates further employer antipathetic action. Consequently, unions may then need even greater degrees of support (legislative, policy) but they are unable to compel this from governments/states because of their underlying weakness and the political insensitivity of political parties to labour unionism.

By contrast, in other, non-Anglo-Saxon, countries such as those found in continental Europe or Scandinavia, anti-unionism of non-union employers exists but its context is sufficiently different to render inclusion in a comparative analysis of Britain, Eire and the US less than worthwhile. This difference historically concerns far greater pro-collectivist and pro-worker state intervention in employment relations (e.g., forums for consultation and co-determination, a positive right to strike), far greater pro-worker public policy like support for centralised bargaining arrangements, and a political centre of gravity which is closer to social democracy than anything that exists in Britain, Eire, and the US. Often there is no perceived need for SURPs applicable to individual employers and sectors in these non-Anglo-Saxon countries. For example, sectors which are elsewhere believed elsewhere to exhibit propensities towards non-unionism by dint of both employee and employer preference like retail, leisure and IT are well unionised and covered by collective bargaining. Financial and other incentives to de-unionisation and derecognition are lessened by the mandatory application of collective bargained 
agreements to the pay and conditions of non-union workers. Thus, the salience of comparing Britain, Eire, and the US rests on their largely voluntarist or collective laissez faire industrial relations systems. However, it also rests on the employment relationship in Eire being relatively more regulated than that in Britain and that in Britain being relatively more regulated than that in the US, albeit within a common neo-liberal political and economic system across the three countries (particularly for Britain and Eire since the 1980s). Consequently, Britain, Eire and the US provide a comparison involving similarity and variability.

This paper poses the preceding argument as a contention to be explored in order to begin to understand the motives, dynamics and context of EA-U. It begins by laying out the contention and its contexts in greater detail before examining the respective situations in each country. The US case is discussed after Britain and Eire because it departs somewhat from the general tenor of the contention. EA-U towards UR campaigns is measured by instances of union substitution and suppression in Britain and Eire and by 'unfair labour practices' (ULPS) in the US which are solely concerned with the SURP and primarily comprise discrimination or firings for union activity and refusals to bargain.

The reason why the argument is expressed as contention (and not a hypothesis to be tested) is two-fold. The first reason concerns the nature of the data and information deployed. In the case of Britain, data was gathered as a part of an research project 
spanning 1990-2007 on UR campaigns and generated through fieldwork (interviews with employed union officers responsible for UR campaigns in the twenty biggest unions) and deploying secondary sources like union documentation and journals, the determinations from the Central Arbitration Committee (the body charged with administering the SURP) and newspaper sources through the Nexis database and those practitioner periodicals which focus on unions. In the case of Eire, data was gathered through the determinations of the state bodies charged with administering the employment disputes procedures (the Labour Relations Commission (LRC) and the Labour Court) and the Industrial Relations $N e w s^{1}$, a fortnightly periodical of industrial relations, and other indigenous press reports through the Nexis database for the same period. Finally, in the case of the US, a review of the salient literature was deployed instead because the relevant period following the introduction of its SURP vastly predated the compatible period for Britain and Eire, making the generation of comparable data extremely difficult, especially given the size of the economy in the US.

In the cases of Britain and Eire, the data generated has a high level of inclusiveness of reported incidences of EA-U, where this concerns documentation in the public domain. In the case of Britain, this was supplemented by interviews. As incidences were selfselecting, no population sample was created and not all incidences will have been captured (owing to deficiencies in union and journalistic reporting systems), it is,

\footnotetext{
${ }^{1}$ This periodical has a high level of inclusion of salient developments due to the small size of the 'industrial relations community' in Eire, the periodical's developed contact network and its high reputation.
} 
therefore, difficult to establish population sizes for the data. It would be wrong to simply conclude that the population size is all employers in both countries, for some will already recognise unions and others being never face any prospect of union activity to gain UR. Consequently, the data should be regarded as highly representative without being fully inclusive. In the case of the US, the literature is based on data from the National Labor Relations Board (NLRB) and episodic, spatially delimited studies of the context for gaining voluntary UR. Because of the former, it cannot be concluded that all incidences of EA-U will have been captured so again a population size cannot be established. Nonetheless, the information for the US can be taken as being highly indicative as seeking UR through the NLRB accounts for c.80\% of all UR attempts by unions.

The second reason why the argument is expressed as a contention relates to the periods and contexts of the SURPs. While the US SURP dates from the inter-war period as part of the Roosevelt administration's self-initiated reform programme (the 'New Deal'), concerned with social cohesion, political stability and economic growth, those in Britain and Eire date from the new millennium and are the outcome of pressure group politics upon government under neo-liberalism. Moreover, levels of extant EA-U to UR campaigns, prior to any SURP impact, were different in the three countries; greatest in the US, and substantial in Britain with Eire being in between but more akin to Britain. These factors mean that variables would need to be constructed in order to take account of these differences in order to make analysis grounded and robust. But, as per 
above, the data does not lend itself to this. Consequently, the discussion and conclusion are of a more suggestive nature, where it should be borne in mind that the size of the labour forces are respectively c150m (US), c30m (Britain) and c2m (Eire) in the new millennium as a rough measure for comparison.

\section{Conceptualising Union Weakness and Employer Anti-Unionism}

Formal recognition of unions by employers as bargaining partners in co-determining the wage-effort bargain is one of the key organisational blocks of labour unionism. Thus, procedural agreements provide the basis for concluding substantive agreements through collective bargaining. Under national systems of industrial relations marked by voluntarism (or collective laissez faire) and formally decentralised and disaggregated employer power and authority structures, ${ }^{2}$ UR provides unions with the firm-level organisational rights to defend and advance members' interests, notwithstanding the need to construct effective bargaining power and build political support for labour unionism. Within such systems, labour unionism is very much - indeed, necessarily more dependent upon its own independently generated resources in order to defend and advance members' interests in relation to employer and state regulatory agencies. Following from this, periods of relative union weakness present unions with particular challenges because of their predicament of resource self-sufficiency under this type of regulatory regime. Here union weakness is characterised by indifference or hostility from government, state and employers, which is underpinned by changes in labour and

${ }^{2}$ The force of these features has been accentuated by the ascendant hegemony of neoliberalism. 
product markets. Faced with shrunken political leverage with government, diminished membership resources - fewer members, decreased membership attachment, lower union consciousness, reduced willingness to mobilise collectively and the like - and decreased qualitative and quantitative bargaining power with employers, ${ }^{3}$ unions have pressed for the creation of SURPs to facilitate gaining UR. ${ }^{4}$ In so doing, unions campaign in the political arena not only to gain agreement from progressive parties (e.g. labour or social democratic parties) to adopt SURP policies but also to put these parties into office in order to implement SURP polices. This strategy of campaigning for regulatory reform attempts to resolve unions' industrial weakness, in recognition of this weakness being largely attributable to successful employer mobilising strategies of opposition (antiunionism, non-unionism), as well as use political means by which to help rebuild industrial strength. What is particularly noticeable about this strategy is that labour unions have spurned their traditional suspicion of reliance on statutory support and legal intervention and fought shy of engaging in direct, bilateral confrontation with employers in battles where there is a marked asymmetry of power.

But union success in obtaining SURPs has not been matched by consequent success in gaining UR itself. The major factor explaining this has been employer behaviour, where the creation, introduction and availability of SURPs have helped to: a) create employer opposition to labour unionism because of the prospect of facing consequent UR

\footnotetext{
${ }^{3}$ Cf. Batstone (1988) on sources of union power: disruptive capacity, labour scarcity and political influence.

${ }^{4}$ Of course, SURPs are not solely attributable to union action. In this regard, the peculiarity of the US vis-à-vis Britain and Eire will be examined below.
} 
campaigns; b) stimulate the transformation of what was previously dormant or latent employer antipathy to labour unionism into active, tangible opposition as a result of hypothetical, potential, expected or actual UR campaigns; and c) further stimulate and deepen existing active and tangible EA-U with regard to UR campaigns. Predictably, this employer opposition is generally effective (see, for example, Cooke 1985a, b), and not just because of superior financial, ideological and organisational resources but also because of the ability to exercise these in de jure and de facto unregulated manners. By contrast, the relatively decentralised nature of the industrial systems means that structural obstacles exist to labour unionism aggregating its power. Moreover, UR campaigns are almost necessarily characterised by nascent, not mature, workplace unionism, making it, arguably, more susceptible to EA-U. These employer actions then represent counter-mobilisation to defend their interests, defined in terms of rights of private property and managerial prerogative, and viewed through their worldview of unitarism by way of capital ownership and possession of management expertise. Moreover, in recent times, the hegemony of unitarism amongst employers has been extended through the ascendancy of HRM, which in turn has helped create a societal environment in which it is not politically unacceptable and not economically cost-laden for employers to behave in a unitarist manner. Indeed, there is legitimacy for taking action to prevent the prospect of employers 'gaining' uncompetitive 'disadvantage' through UR.

\section{Statutory Union Recognition Procedures as Facilitators of Employer Anti-Unionism}


What is particularly important in facilitating EA-U is that the SURPs are enabling provisions, for they do not guarantee UR per se. Rather, they provide for UR if a procedure is passed through and if certain criteria are met. This is more important than any particular characteristic of SURPs for it allows employer interference to prevent or weaken the union's case in the critical arena of the workplace where union membership and worker support exist and where the employer's strength is dominant. Consequently, the promise or potential of SURPs for unions gaining UR with non-union employers is unrealised, either in getting to the point of an application or during the determination of the application. On top of this, the criteria are often exacting ${ }^{5}$ and the procedures allow for de jure employer interference as both employers and unions can be charged with ULPS.

At a conceptual level, the existence of SURPs can be taken by non-union employers to pose a threat because, despite its varied but weak complexion in the three countries, it offers the probability of stimulating fresh, and reinvigorating existing, UR activity and provides an avenue through which to channel this activity which fundamentally questions the managerial prerogative. To non-union employers, SURPs then signal a hostile and aggressive act against capital and for labour, even though no mainstream political party or state apparatus in any of the three countries has ever displayed the

${ }^{5}$ This is attributable to employer action: having accepted the realpolitik that SURPs would be created, employers, through lobbying, successfully ensured that the SURPs would be as 'business-friendly' as possible (see, for example, Gall 2004a:254 and Gross 1974, 1981, 1995). Following from this, a number of authors like Ewing et al. (2003) and Moore (2004) have argued that the complexion of the SURPs allows and facilitates employer interference and resistance. 
political ideology or political will to legislate for a SURP that would justify such employer anguish (such as one which gave workers an inalienable right to UR for individual workers or a simple collective of workers. i.e., two or more workers). Moreover, the degree of employer anguish particularly focuses on the use of law or regulation, rather than just public policy support, for UR.

The means by which non-union employers mobilise and utilise their resources are welldocumented, ranging from the 'velvet glove' to the 'iron fist or union substitution to union suppression which reward non-unionism and imposes costs on union members respectively (see Gall 2004b). The three situations in which the processes of employer mobilisation occur are hypothetical, potential and actual. In the hypothetical, the employer is unaware of any specific unionisation activities (internal or external) but believes that the prospect and existence of the SURPS are likely to stimulate attempts to undertake unionisation and recognition activities because of the existence of grievances and underlying discontent within their workforce. Initiatives are then taken to pre-empt such activities. In the potential, the employer is aware of some recent attempts at unionisation activities (internal or external) and believes that the prospect and existence of SURPs are likely to further stimulate or reinvigorate attempts to increase union membership with the express aim of gaining UR. Initiatives are then taken to pre-empt their return or further development. In the actual, the employer is keenly aware of current attempts at unionisation and recognition campaigning, and believes that the prospect and existence of SURPs are likely to further stimulate or reinvigorate attempts 
to increase union membership and gain UR. Moreover, the employer believes that the SURPS will tip the balance in favour of the union resulting ultimately in the granting of legal UR. Initiatives are then taken to end the current unionisation and UR campaigns. The paper now proceeds to examine the contention in the three countries.

\section{Employer Anti-Unionism in Britain}

Prior to 1995, the extent of non-unionism grew by virtue of unions' inability to organise new, greenfield sites (Millward et al. 2000). This inability was more closely related to unions' limited 'reach' - both orientation towards greenfield sites and the resources deployed therein (Heery et al. 2000, Snape 1994)- rather than EA-U there. Derecognition had also been growing (Gall and McKay 1994) while the few attempts to gain new UR agreement were met by a high degree of EA-U (Gall 1993). Between 1995 and 2007 , union density fell from $32.6 \%$ to $28.0 \%$ and from $21.6 \%$ to $16.1 \%$ in the private sector (Mercer and Notley 2008:17, 19). From 1995 onwards, two significant processes were set in train. Firstly, it became clear that the Labour Party would win the forthcoming general election and legislate on its policy of establishing a SURP where a majority of the workforce wished it, which it did in 1999 (Employment Relations Act 1999) with the SURP 'going live' in 2000 . However, this did not mark a move away from collective laissez faire (Smith and Morton 2001). Secondly, the TUC spearheaded the promulgation of 'union organising', leading to its relatively wide adoption. Consequently, union activity to win new UR agreements increased markedly as a result 
of the ability to operate more successfully by dint of the more conducive environment (Gall 2004a, Table 1).

Table 1 (columns 2,3,5) shows that in absolute numbers, the level of EA-U increases from a low base to the point (2000-02) of the introduction of a SURP and the apex of the number of UR campaigns before falling back in line with the decreasing number of UR campaigns. However, neither introduction of the SURP nor the rise in UR campaigns led to a relative and sustained increase in EA-U across the period (column 5 ), and by the end of the period, it remained broadly at the same level as at the start. Nonetheless, from 1995 - when it became Labour would win the election and legislate for a SURP - to 1998 - when the (pre-Bill) White Paper for the SURP was published, the relative level of EA-U increased. Table 1 also shows that the deployment of strikes and strike threats to gain UR increased in absolute terms before falling back to the level of the early 1990s by 2007, being influenced by the overall decline in strikes and the availability of a SURP while, when correlated to the number of UR campaigns in relative terms, fell from 1990 to 2007. The number of UR campaigns rose considerably from 1990 to 2001, before falling back by 2007 (but not to pre-1995 levels). Meantime, the number of new UR agreements follows the same pattern in absolute numbers of substantial increase to 2000-02 but in relative terms, the number of agreements gained as a proportion of campaigns run experienced a substantial fall from the 1999-2001 period. 
Table 1: Union Tactics and Employer Tactics in Recognition Campaigns, 1990-2007

\begin{tabular}{|c|c|c|c|c|c|}
\hline Year & \begin{tabular}{|l|} 
Total \\
number of \\
EA-U \\
incidents \\
\end{tabular} & $\begin{array}{l}\text { Number of } \\
\text { employers } \\
\text { using EA-U } \\
\text { tactics }\end{array}$ & $\begin{array}{l}\text { Number of strikes / strike } \\
\text { threats used to try to gain UR } \\
\text { (\% of UR campaigns both used } \\
\text { in) }\end{array}$ & $\begin{array}{l}\text { Number of UR campaigns } \\
\text { run (\% affected by EA-U } \\
\text { tactics) }\end{array}$ & $\begin{array}{l}\text { Number of new UR agreements } \\
\text { signed (\% of which campaigns for UR } \\
\text { successful) }\end{array}$ \\
\hline 1990 & 17 & 11 & $3 / 4(10 \%)$ & $71(15 \%)$ & 49 (69\%) \\
\hline 1991 & 19 & 10 & $2 / 3(5 \%)$ & $99(10 \%)$ & $76(76 \%)$ \\
\hline 1992 & 13 & 9 & 3 /3 (7\%) & 83 (11\%) & 56 (67\%) \\
\hline 1993 & 20 & 10 & $2 / 3(6 \%)$ & $88(11 \%)$ & 57 (65\%) \\
\hline 1994 & 25 & 11 & $3 / 2(7 \%)$ & $71(15 \%)$ & $27(38 \%)$ \\
\hline 1995 & 35 & 18 & $3 / 3(6 \%)$ & $109(17 \%)$ & $88(81 \%)$ \\
\hline 1996 & 55 & 31 & $2 / 2(3 \%)$ & $159(19 \%)$ & 86 (54\%) \\
\hline 1997 & 78 & 52 & $3 / 3(3 \%)$ & 207 (25\%) & 109 (53\%) \\
\hline 1998 & 113 & 68 & $2 / 4(2 \%)$ & $296(23 \%)$ & $128(43 \%)$ \\
\hline 1999 & 143 & 85 & $4 / 6(2 \%)$ & 665 (13\%) & 365 (55\%) \\
\hline 2000 & 160 & 107 & $8 / 11(2 \%)$ & $1097(10 \%)$ & 525 (48\%) \\
\hline 2001 & 163 & 101 & $7 / 10$ (1\%) & $1489(7 \%)$ & 685 (46\%) \\
\hline 2002 & 203 & 113 & $6 / 9(1 \%)$ & $1138(10 \%)$ & $388(34 \%)$ \\
\hline 2003 & 155 & 98 & $5 / 8(2 \%)$ & 704 (14\%) & 259 (37\%) \\
\hline 2004 & 75 & 57 & $4 / 4(1 \%)$ & $589(10 \%)$ & 239 (41\%) \\
\hline 2005 & 45 & 30 & $3 / 3(2 \%)$ & $276(11 \%)$ & $122(44 \%)$ \\
\hline 2006 & 40 & 25 & $3 / 4(3 \%)$ & $222(11 \%)$ & $83(37 \%)$ \\
\hline 2007 & 39 & 23 & $3 / 3(2 \%)$ & $241(10 \%)$ & 94 (39\%) \\
\hline Totals & 1398 & 859 & $66 / 85(2 \%)$ & 7604 (11\%) & $3436(45 \%)$ \\
\hline
\end{tabular}

Notes: Column data is not exclusive of each other. For example, a union may experience EA-U, threaten a strike to gain UR and gain UR. EA-U incidents are single instances of employer anti-unionism.

Therefore, Table 1 provides some broad support for the contention but suggests that in the case of Britain, refinement is needed. Thus, in absolute terms, the level of EA-U does not fall below the pre-1995 level after 2000. However, in relative terms it does but where the highest level of EA-U is in the period of the creation of the SURP and the runup to its introduction rather than its availability per se. This suggests that a higher proportion of employers subject to UR campaigns sought to resist it in the window of opportunity before 2000 while, proportionately, fewer did after 2000 . Yet, this must be balanced by the recognition that many more in absolute numbers resisted when faced with UR campaigns after 2000. The fall in the number of UR campaigns and new UR 
agreements (along with the success rate) after the apex of 2000-1 represents arguably a combination of, on the one hand, union fatigue and the paucity of union resource after initial investment in UR campaigns, and on the other, the decline in the extant proportion of more amenable employers and the rise in the extant proportion of less amenable employers, whereby unions have gained success amongst the former and then moved to try to win UR from the latter (Gall 2007). Amongst the latter, preemptive actions to ward off unions from mounting UR campaigns would seem to have been successful. Within these shifts, the decline in strike and strike threat usage is not indicative of less EA-U but availability of recourse to a SURP. Finally, the EA-U is more associated with actual and expected, rather than hypothetical, campaigns (Gall 2004b). The contention of SURPs stimulating EA-U is also broadly supported by other research (see, for example, Ewing et al. 2003, Heery 2000, Heery and Sims 2003, 2006, Moore 2004) and consistent with growing EA-U attitudes (Cully et al. 1999:87-89, Kersley et al. 2006:113-115 $)$. For these reasons, the union movement has lobbied for changes to the SURP, achieving very minor reforms in the Employment Relations Act 2004.

\section{Employer Anti-Unionism in Eire ${ }^{7}$}

In Eire, no political party displays an anti-union weltanschauung (cf. Britain, US), and unions are (relatively influential) social partners at the societal level (Gunnigle et al.

\footnotetext{
${ }^{6}$ Unfortunately, the fourth Workplace Employment Relations Survey (Kersley et al. 2006:113114) only measures the preponderance by certain types of employer size and ownership structure towards anti-unionism in terms of discouraging union membership. Moreover, this takes place in both recognised and non-recognised workplaces. The same is true for both Eire and the US in as much as there are no large scale national surveys which measure EA-U.

${ }^{7}$ As the case of Eire is relatively less well-known, a more detailed background is provided.
} 
2001). Nonetheless, there is relatively little legal regulation of the employment relationship, with the tradition of voluntarism pronounced. In this context, and with the ascendancy of employer power, the extent of UR has fallen in over the period under study (Gunnigle et al. 2002:8, Roche 2001:44). D’Art and Turner (1999), McGovern (1989) and Turner et al. (1997) recorded increasing EA-U since the early 1980s to granting UR, resulting in growing recourse to the Labour Court and striking. The rise in non-unionism resulted also from the establishment of new, non-union workplaces, where union avoidance on greenfield sites was marked (Flood and Toner 1997, Gunnigle et al. 2002:10, Gunnigle et al. 2005, Roche 2001:46, 50). Opposition ranged from substitution to suppression, despite moves to accommodate to employers through sweetheart, partnership and partial recognition agreements. This downward trend in UR matches the decrease in union density, falling from $62 \%$ in 1980 to $35 \%$ in 2005 , with private sector density of 21\% in 2005 (EIRO 2002, 2005).

Despite union pressure in the mid- to late-1990s to move to statutory underpinning for collective bargaining (the 'duty to bargain' policy) rather than UR per se, the voluntarist and non-legal approach deploying the Labour Court and LRC continued. But the Ryanair dispute (Roche 1998) increased union resolve to gain a strengthened procedure. This bore fruit in 1999, leading to the Labour Relations (Amendment) Act 2001. Although the voluntarist approach was retained, the Labour Court was now able to issue legally binding recommendations compelling employers to bargain with their unionised employees where an employer rejects the revised and extended voluntary recognition 
process or deliberately abuses it. While this voluntary process can take up to two years, the Labour Court's recommendation exists for one-year initially and, if unresolved, a final binding recommendation can be issued. The unions did not favour adopting the British form of SURP, believing protracted legal disputes would occur, derecognition would be stimulated and inward investment discouraged. As such, the 'right to bargain' constitutes a dispute resolution procedure, and not a SURP providing for non-temporary representation. However, it does represent a de facto albeit peculiar SURP, with which the union movement soon expressed disappointment with its outcomes (D'Art and Turner 2003:234). Consequently, it sought to strengthen the procedure for gaining bargaining rights and UR, now moving to adopt the British form of SURP in 2002, while maintaining the 'right to bargain' legislation but with a shortened time scale. As part of the negotiations for the next social pact, the former demand was won (through the 2004 revised Industrial Relations (Amendment) Act 2001) and all the social partners recognised that this was unlikely to be a final settlement given the influence of developments in the European Union's social agenda.

The extent of EA-U can be judged by the volume of Labour Court cases, strikes for UR, and reports of salient employer behaviour alongside the number of UR campaigns outwith the state procedures. Since the introduction of the new procedures (voluntary, 'right to bargain' and revised 'right to bargain'), union activity has increased significantly in seeking UR using the state-sponsored provisions (Labour Court 1992-2007, EIRO 2002, Tables 2 and 3). Thus, in regard of the LRC for example, between May 2000 and October 
2001, 28 applications were made while between October 2001 and September 2002, this number doubled (EIRO 2002). However, the result of the applications, most of which have not gone through the full procedure including the 'right to bargain', is poor, and unions were concerned that employers were using the procedures to lawfully engage in delay and obfuscation (EIRO 2002) as well as take advantage of the lowered ability of unions to take industrial action within the procedures. In addition, both Roche (2001) and EIRO (2005) noted a hardening of EA-U attitudes.

In terms of Labour Court cases for gaining new UR agreements (Table 2), the decline to the mid- to late-1990s indicates the difficulties unions experienced in bringing forward strong cases due to EA-U. With the strengthening of the SURP, the number of cases increases towards 2006. Although the Labour Court makes quasi-binding recommendations, there is only a 30\% compliance rate (Gunnigle et al. 2002:235), and this level of employer resistance to granting UR is paralleled in LRC cases (D'Art and Turner 2003:127, 234) since 2000. EA-U here comprised denial of access to workers, and an array if union suppression and substitution tactics (D'Art and Turner 2005:129). Collectively, these factors concerning EA-U have led a poor union success rate for the period 2004-06 where the SURP provisions are now ostensibly the strongest they have ever been and a dramatic fall in applications in 2007 (Table 2). 
Table 2: Labour Court Cases on Union Recognition, 1990-2007

\begin{tabular}{|l|l|l|l|l|l|l|l|l|l|l|l|l|l|l|l|l|l|l|}
\hline Year & 19 & 19 & 19 & 19 & 19 & 19 & 19 & 19 & 19 & 19 & 20 & 20 & 20 & 20 & 20 & 20 & 20 & 20 \\
0 & 91 & 92 & 93 & 94 & 95 & 96 & 97 & 98 & 99 & 00 & 01 & 02 & 03 & 04 & 05 & 06 & 07 \\
\hline $\begin{array}{l}\text { UR } \\
\text { cases }\end{array}$ & 6 & 22 & 13 & 10 & 17 & 11 & 9 & 12 & 7 & 10 & 7 & 8 & 5 & 18 & 23 & 34 & 36 & 7 \\
\hline $\begin{array}{l}\text { Cases } \\
\text { concerning } \\
\text { gaining } \\
\text { new UR }\end{array}$ & 4 & 17 & 10 & 10 & 10 & 8 & 6 & 6 & 4 & 6 & 4 & 6 & 5 & 16 & 22 & 28 & 27 & 7 \\
\hline $\begin{array}{l}\text { Cases of UR } \\
\text { recommended }\end{array}$ & 3 & 17 & 10 & 10 & 9 & 7 & 6 & 5 & 3 & 5 & 1 & 0 & 3 & 9 & 2 & 4 & 3 & 0 \\
\hline
\end{tabular}

Source: Gunnigle et al. (2002:11) for years 1990-1999 for rows three and four, and the Labour Court for all other data, with advice from Niall Cullinane (University of Galway) on interpreting data categories since 2001 in the light of the 'right to bargain' legislation.

Note: The number of cases and recommendations are not synonymous with the number of applications for a number of applications were withdrawn because of developments in the voluntary arena or were discounted by the Labour Court.

Despite the SURPs in Eire being weaker in de jure and de facto terms than those which exist in Britain and the US, two points are salient. For employers, there is still a purpose and incentive to mobilise against UR applications because the newer procedure exhibits a greater propensity to force them recognise and bargain with unions, and unions have been stimulated to use the procedure so that their recognition activities are greater than has hitherto been the case. For the unions, despite the procedure's limitations, they now potentially have some further leverage over EA-U than was hitherto the case and this is an incentive to organise. Moreover, it is discernible that the level of EA-U has increased as the SURPs have become relatively more pernicious to non-union employers' interests. Indeed, Table 3 broadly shows this, where the anticipation of a SURP, the existence of a SURP itself and the attempts to strengthen the SURPs can be seen to flow through to union organising which stimulated EA-U. Thus, in Table 3, the periods 1998-2000 and 2002-06 are noticeable by virtue of higher levels of EA-U compared with the pre-1998 period while in Table 2, the period 2003-06 is noticeable for attempts to gain new UR. But, as with in Britain, the level of EA-U falls off towards 
the end because of, on the one hand, union fatigue and paucity of union resource in mounting UR campaigns, and paradoxically on the other, the decline in the proportion of more amenable employers.

Table 3: Union Tactics and Employer Tactics in Recognition Campaigns

\begin{tabular}{|c|l|l|l|l|l|l|l|l|}
\hline Year & $\begin{array}{l}\text { Strike } \\
\text { (strike } \\
\text { threat) }\end{array}$ & Works council & $\begin{array}{l}\text { Direct } \\
\text { communi- } \\
\text { cation }\end{array}$ & $\begin{array}{l}\text { Selective sackings } \\
\text { /closure threat }\end{array}$ & $\begin{array}{l}\text { Stone- } \\
\text { walling/ } \\
\text { access denied }\end{array}$ & $\begin{array}{l}\text { Company } \\
\text { Ballot }\end{array}$ & $\begin{array}{l}\text { Year } \\
\text { total }\end{array}$ & $\begin{array}{l}\text { Number of } \\
\text { new voluntary } \\
\text { UR deals }\end{array}$ \\
\hline 1995 & $1(0)$ & 1 & 1 & 0 & 3 & 0 & 6 & 2 \\
\hline 1996 & $1(1)$ & 1 & 3 & 0 & 3 & 0 & 9 & 1 \\
\hline 1997 & $1(0)$ & 1 & 1 & 2 & 5 & 0 & 10 & 1 \\
\hline 1998 & $1(3)$ & 2 & 1 & 4 & 12 & 1 & 24 & 2 \\
\hline 1999 & $6(1)$ & 2 & 1 & 2 & 10 & 0 & 22 & 2 \\
\hline 2000 & $4(1)$ & 2 & 1 & 2 & 10 & 0 & 20 & 2 \\
\hline 2001 & $0(4)$ & 1 & 0 & 0 & 6 & 0 & 11 & 3 \\
\hline 2002 & $4(3)$ & 3 & 2 & 2 & 11 & 0 & 25 & 3 \\
\hline 2003 & $7(1)$ & 3 & 3 & 1 & 14 & 0 & 29 & 6 \\
\hline 2004 & $0(1)$ & 5 & 3 & 0 & 6 & 2 & 17 & 10 \\
\hline 2005 & $0(2)$ & 7 & 3 & 1 & 7 & 0 & 20 & 4 \\
\hline 2006 & $1(2)$ & 3 & 4 & 1 & 6 & 0 & 17 & 3 \\
\hline 2007 & $1(2)$ & 2 & 3 & 1 & 5 & 0 & 15 & 2 \\
\hline Totals & $30(21)$ & 33 & 27 & 16 & 98 & 3 & 228 & 41 \\
\hline
\end{tabular}

Note: $\mathrm{N}=126$ employing organisations, so that each organisation may have used more than one tactic $(\mathrm{N}=177)$.

\section{Employer Anti-Unionism in the US}

The extent and depth of EA-U to UR campaigns is legendary in spite of the existence of a SURP since 1935. For example, between 1993 and 2003, an average of 22,633 workers pa were ordered to receive back pay from their employers for being fired or discriminated against for their union activities or sympathies (American Rights at Work 2006, see also Cooke $1985 b)^{8}$. This equates to some $28 \%$ of employers faced with UR elections sacking union activists/members/sympathisers (Bronfenbrenner and Juravich

${ }^{8}$ Data on discrimination against labour unionists is derived from NLRB figures, where some $90 \%$ of cases are concerned with organising drives (Cooke 1985b) and NLRB certification elections represent some $80 \%$ of all attempts to gain UR. 
1998:22). Even though reinstatement is ordered, subsequently many are hounded out of their jobs (Kleiner 1984). Now, and despite tremendous difficulties in the voluntary arena, some unions assert that using the National Labor Relations Board (NLRB) procedures is entirely counter-productive because it provides EA-U with so many opportunities, and with virtual impunity, to defeat their attempts. Rather, these unions now seek to build up substantial union membership before requesting neutrality agreements from employers prior to voluntary card checks or voluntary ballots (Fiorito 2003, Jordan and Bruno 2006). And, moreover, unions have campaigned for and sponsored legislation on several occasions (the Labour Law Reform Act (1977-8) and Employee Free Choice Act (2007-9)) to make the SURP more 'union friendly'. Union density has risen and then fallen from $32 \%$ in 1953 to $12 \%$ in 2008, with density in the private sector peaking at 36\% in 1953 and falling to 7\% in 2006 (Moody 2007:100).

The creation of the SURP can be likened to a 'reform from above' rather than a 'revolution from below' in that the labour movement, then represented by the conservative American Federation of Labor (AFL) did not campaign for nor advocate such a proposal. Rather, National Labor Relations Act (NLRA) formed part of the 'New Deal' programme, seeking to institutionalise workplace conflict and promote workplace cooperation and industrial democracy. More widely, the 'New Deal' sought to reject unitarism and neoclassical economics and move towards pluralism and Keynesian with the purpose being to create social justice and peace, stabilise and expand the economy, and cohere society (Cohen and Cohen 1948, Clawson 2003, Clawson and Clawson 1999, 
Fiorito 2003, Gross 1985, Kochan et al. 1984, Renshaw 1991, Roomkin 1981). In this light, the 'New Deal' can be viewed as a centralised, top-down organised accommodation, introduced without extensive tripartite means, between the interests of capital and labour and led by a distinct political force ( $c f$. those class accommodations in Scandinavia in the same epoch which were derived from intense capital-labour conflict and tripartite talks). Moreover, the labour movement would have been unable, had it wished, to compel the creation of a SURP because of its industrial and political weakness at this point (cf. 1935-1955 with the rise of the Congress of Industrial Organisations $(\mathrm{ClO}))$. Thus, the NLRA did not represent an attempt by organised labour to regain its former influence for organised labour had not yet reached its historical apex of strength. Indeed, helped by the NLRA, and in tandem with the militancy and mobilising power of the $\mathrm{ClO}$ and the expansion of the economy from the early 1940s onwards, organised labour reached its historical apex between 1960 and 1970 (Kochan 1980, Moody 1986).

The salience of this sketch is that the introduction of a SURP did not provide an immediate, substantial fillip to industrial EA-U. Indeed, EA-U appears to be greater and more violent prior to 1935, and while there was employer resistance (Gross 1981:7-9, 13, 17-18), its main form was initially political and legal redress (Gross 1974, 1981), following imposition upon a generally unwilling party - non-union employers - within a changed and less hospitable political environment. Consequently, this strategic orientation, which suppressed industrial EA-U, stood on the basis of vehement 
contemporary anti-unionism, which was of hypothetical, potential and actual types (see Bendix 1956:267-274, Bernstein 1960). Although SURP cases are not synonymous with all cases of UR campaigns, in its early years of operation the degree of synonymousness was very high (Logan 2001:65). Compared to later on, the marked feature of the NLRA's early period (1935-1947) was a relatively low level of elections $(<3,000)$ but with a high (>75\%) rate of success (Fulmer 1982:182-183). The former reflected limitations on union organising capacity while the later reflected the nature of the period, whereby the move towards a collectivist ideology and welfare capitalism, organised labour's growing strength, the expansion of the economy, rising rates of profitability and the 'unifying' impact of the Second World War (WWII) inclined employers, generally speaking, towards accommodation rather than opposition (although this may not have been the case if more UR elections were faced).

Nonetheless, the significance of this political opposition to the NLRA from various pressure groups, the press, employers and politicians (Adams 1999, Cohen and Cohen 1948, Gross 1995, Kochan et al. 1984, Logan 2001, Moody 1986, Renshaw 1991) lay in its portent for future years. While the Smith Bill of 1940, which was intended to undermine the 1935 settlement, became stillborn as a result of WWII, the NLRA experienced a counter-offensive after the enforced social peace of WWII ended in the form of the Labor Management Relations (Taft-Hartley) Act 1947 and Landrum Griffin Act 1959 (Gross 1981). These not only weakened NLRA but their spirit fed through to NLRB (Gross 1981, 1985, Fiorito 2003, Kochan 1980), whereby employers were expressly 
authorised to oppose UR and penalties against management ULPs were so low as to be ineffective deterrents ( $c f$. Abelow 1958, Cohen and Cohen 1948). Nevertheless, actual EA-U was still marked (see Bernstein 1970, Zeiger 1997), testifying to latitude of action amongst employers per se.

From 1950 onwards, the number of UR elections rose from c5,600pa to a high point of c8,500 in 1973 (although not steadily) before falling back to c7,000 in 1980 (Fulmer 1982:2). There was a particularly sharp fall from $1980(7,296)$ to $1983(3,492)$ (Moody 1986:124). Previously, there were 1,100 elections in 1940 (Lipset and Katchanovski 2001:237) while by 1997 the number had fallen to under 3,300 in 1997 and to just over 2,100 by 2006 . A general consensus exists that EA-U has had a significant if unspecified role in reducing the number of UR elections (these themselves stemming from prior petitions and a priori union assessment of success). Meanwhile, the success rate for unions in recognition elections fell fairly evenly from $74 \%$ in 1950 to $49 \%$ in 1980 (Fulmer 1982:2). Indeed, the decline in the success rate is even more remarkable when one considers that it was as high as 94\% in 1937 (Fulmer 1982:182) and fell to 46\% in 1985 before moving back up to around $50 \%$ in many of years from the early 1990 s onwards (Jordan and Bruno 2006:182, Lipset and Katchanovski 2001:237, see also Cooke 1983:402 and Freeman 1986:45). ${ }^{9}$ The number of alleged management ULPs increased from c3,000 in 1937 to c30,000 by 1979 (see also Roomkin 1981:246 and Meyer and Cooke 1993:553). After reaching a high point in the early 1980s, the number of ULPs fell

\footnotetext{
${ }^{9}$ Concurrently, the number of workers covered by these wins has continued to fall significantly.
} 
back somewhat before reaching a new high in 1997 (see McCammon 2001:144). This overall upward trajectory led Freeman and Kleiner (1990:351) to comment that ULPS had 'skyrocketed' in the 1970s and 1980s. According to Flanagan (2005:48), these ULPS fell back a little by 1999 (cf. Logan 2001:67). Both Kleiner (2001:522) and Logan (2002:198) also reported on the huge growth in anti-union consultants between late 1960 s and early 1980s. Another way of looking at these issues can be gained by considering the percentages of NLRB elections that were not contested by employers. These fell from 47\% in 1963 to $8 \%$ in 1978 (Seeber and Cooke 1983:43).

Concomitant, the percentage of successful recognition elections not leading to a first collective bargaining contract rose from $20 \%-25 \%$ in the 1970 s to $33 \%-37 \%$ in 1980 s (Cooke 1985a:164, Clawson and Clawson 1999:103, Freeman and Kleiner 1990:351, McDonald 1986:61 (see also Pavy (1994) and Jordan and Bruno (2006:183)). Kleiner (2001:524) reported a rise in 'bad faith' bargaining from less than 2,000 cases pa in 1950 to over 10,000 in the 1990 s. Freeman and Medoff (1984:240) also noted that decertification elections, although remaining relatively infrequent vis-à-vis UR elections and often initiated by employers, picked up from 1970s (see also Logan 2001:66). Although not uncontested (Dickens 1983, Fiorito 2001, 2002, Freeman and Kleiner 1990, Keoller 1992, and Farber and Krueger 1993, Lipset and Katchanovski 2001, Flanagan 2005), Freeman (1986:54-61), surveying the extant research, argued that 'managerial opposition matters', contributing between $25 \%$ to $50 \%$ of the explanation for union 
losses in UR elections where management ULPs were used (Freeman 1986:59) while others like Gross (1995:279) went further.

To summarise, the most widespread EA-U took place well after the SURP's introduction, suggesting either the introduction of mechanism did not itself produce this anticipated outcome or the anticipated outcome was deflected and delayed rather than dissipated. Generally speaking, the employers were either not inclined to oppose the growing number of UR campaigns because it was politically and industrially inopportune, and/or the threat posed by UR to their interests was insufficient to warrant such opposition. Various commentators have supported an interpretation. The first view attaches significance to organised labour's growing power and the settled nature of the pluralist and Keynesian political accord in moulding employer behaviour. The second view attaches significance to the economic expansion and growing rates of profitability that capital enjoyed. There is, however, disagreement amongst such commentators as to when the turning point took place with regard to significant change in these environmental factors. For example, Dubofsky (1994), Gould (1994) and Klein and Wanger (1986) favoured the late 1940s/1950s while Clawson (2003:37), McCammon (2001), Meyer and Cooke (1993) and Moody (1986, 2007), for example, cited the 1970s and early 1980s. Thus, differences exist over the influence of the Taft-Hartley Act 1947 and the developing case law (Kochan et al. 1986:33). The case of Dubosky et al. rests largely on the ending of the wartime enforced social peace and slowing down of economic growth while the case of Clawson et al. rests largely on the ending of 
economic growth and profitability. Meanwhile, Gross (1995), and others like Logan (2001) and Towers (1999), suggested that the level of EA-U grew steadily and exponentially from 1935. Gross $(1995: 202,240,278)$ outlined the emergence in the 1960s of the Labor Law Reform project marking the beginning of organised and widespread political counter-mobilisation, while the defeat of Labor Reform Act in 1978 represented another ratcheting up of EA-U.

\section{Discussion}

There are four areas now worthy of discussion; applicability of the contention, the generic nature of SURPs, the ramifications of the capital-labour-state relationship, and the agency of management.

The first concerns the case of the US. It is not so much the exception to, or that proves, the 'rule' but rather a reminder that a general rule is merely that and should, thus, be applied with sensitivity to specific situations. So while in the US, organised labour did not campaign for, never mind achieve a SURP, it did significantly benefit from one up to a point - that being when employers decided that it was opportune and/or necessary time to mount widespread resistance. Thus, political and economic circumstances conditioned employers' response both in terms of when they did and did not resist industrially. But once EA-U to UR through the SURP was deemed possible and necessary, it was routinely engaged in. The situation in Britain and Eire is a variation of this theme: weakened labour movements were sufficiently influential to gain weak SURPs thus stimulating the generation of EA-U. Thus, employers were insufficiently strong politically 
to prevent the creation of a SURP but they were sufficiently strong politically to influence its complexion and sufficiently strong industrially to limit its impact through EA-U. However, in Eire, with a very weak SURP, it is reasonable to suggest counterfactually that EA-U there would have been greater had a British-type SURP been introduced. Two other qualifications are warranted. First, that in relative terms and with regard to Britain (and probably Eire), EA-U prior to the introduction of a SURP is greater than after its introduction for non-union employers recognised there was more latitude for it prior to the introduction of the new regulatory regime and less afterwards. But even here EA-U after the introduction of a SURP is still significant and leads to less UR campaigns being mounted. Second, SURPs lead to unions focusing and structuring their UR activity in such a way (sic) that puts a greater premium on EA-U targeted at potential and actual situations of UR activity.

Second, and with that said, it is not just that the particular procedural nature of SURPS that leads to EA-U as some (Adams 1999, Logan 2001) have suggested but their existence per se, albeit guided by the balance of prevailing political and economic forces. Their existence is be taken by some non-union employers as an affront to their self-ordained rights as capital, and they have the means by which to resist (albeit that the battle to determine the procedural complexion of SURPs is still important for employers for this can make their task of resisting more, or less, easy). However, what is salient about the nature of SURPs is that they are of an enabling and not automatic nature, whereby UR is granted where specific conditions and thresholds are met, and 
are inserted into voluntarist regimes where the power and resources imbalance at work between labour and capital is reified. Thus, employers are invariably free to deny union access to workers and free to intimidate, cajole and coerce their workers into refusing to entertain a union. Consequently, such non-union employers are able to deploy substitution and suppression tactics to not only defeat UR campaigns but the prefigurative stage of workers joining of unions. Moreover, such wilfully non-interventionist regimes make workers susceptible to EA-U as workplace unionism is nascent here. This means it is unable to create the required degree of independent resources quickly enough through increasing membership and establishing organisation to resist and outflank these non-union employers.

Third, prior to the campaigning for and the introduction of SURPs in Britain and Eire, workplace and national unionisms had reached their post-war zeniths, aided by expanding economic growth, oppositional ideologies and not unsupportive wider government policies. The move from vibrant, powerful and coherent mobilising organisations to atrophied, vanquished and fragmented organisations led to the national labour movements reassessing their own voluntarist traditions. In the US, the SURP helped labour unionism expand and develop when set alongside and infused with the impact of expanding economic growth, oppositional ideologies and not unsupportive wider government policies. In this vein, the contrast of the third SURP in Britain with the first and second versions (1971-4, 1976-9) is instructive to understanding some of the underlying dynamics of the context of the present version. 
The first version was hardly used at all because it resulted from a government initiative against the wishes of labour unionism, which was fearful of legal intervention and at its apex of strength (Gall 2003:15). Meanwhile, the second and stronger version resulted from a social contract between unions and Labour government whereby a new state arbitration and conciliation agency was established. It elicited a still small (albeit much greater) usage than the first because of continued union strength and preference for voluntary means (Gall 2003:15-16). Where binding recommendations were made, refusal to adhere by employers was common and graphically illustrated in a labour cause celebre case (of Grunwick). By contrast, in Eire, although the constitutional right to form and join unions has long existed, declining power under a voluntarist workplace regulatory regime has compelled unions to campaign for a SURP. Consequently, the complexion and operation of SURPs needs to be located in different spatial and temporal dimensions of power and ideology in regard of capital, labour and the state.

Following from this, the major inference to be drawn here is that labour unionism's pursuit of SURPs as a means of revitalisation is futile if too much emphasis is placed on the renewing power of SURPs alone because they are merely one aspect of the wider environment in which unions operate. Concentrating on improving public policy and wider employment legislation is also vital to enhance the prowess of a SURP for SURPS, in the first instance, channel existing labour union strength rather than augment it. Other levers of industrial and economic power of labour unionism (Batstone 1988) need to be developed to counter the power of capital for SURPs not only reflect but can 
reinforce and reify (rather than alter) its hegemonic power, interests and ideology in society. This is because, on the one hand, governments (and states) of whatever hue cannot be neutral or independent of capital under capitalism and, on the other, capital seeks to use its superior resources to defend its interests in whatever arenas it deems necessary to do so in. Consequently, a policy of developing industrial militancy may present a productive means to supplement other modus operandi.

Fourth, data analysis of employer EA-U against UR in both Britain and Eire ${ }^{10}$ shows no clear pattern by workforce size, multi-site status, nationality of employer origin (primarily 'indigenous' versus 'foreign'), economic sector, market share or profitability (or by bunches of variables). This lack of differential association between any of these categories and preponderance to engage in EA-U against UR, regardless for the moment of issues concerning order of causation, suggests that the source and context of the decision to engage in EA-U is to be located elsewhere. So one plausible explanatory variable here might then be management ideology, whether broadly pluralist or unitarist. However, this is too blunt a variable, particularly because it is unable to identify context and causation, such as whether the extant management ideology is the property of the employer or the particular management in post, or whether it arises as result of previous experience of unions (in general or in the individual salient case at hand) or general views of unions. Unfortunately, the research data was unable to shed light on these issues because this level of detail was absent as a result of the research

\footnotetext{
${ }^{10}$ Such an analysis in the case of the US data was not possible because the NLRB data lacks such contextual depth.
} 
methods used. Nonetheless, it appears as a plausible differentiating variable, indicating that not all employers approach the issue in the same way. Equally plausible too as a salient variable would be the strength of UR campaigns. In both Britain and Eire, members of the bodies responsible for administering the SURPS have reported that resisting employers have tended to oppose UR relatively more vehemently where there was a strong chance of statutory UR being granted. In other words, on a temporal costbenefit analysis, employers deduced that resistance was appropriate. This point might be true also for the voluntary sphere for UR. Again, this would highlight the importance of management room for discretion as well as choices then made and the consequent action, albeit that choices can vary, leading to varying actions. This brief discussion highlights the importance of considering management not only as a conscious actor with choices mediated by environmental factors but also as an actor informed by the dialectic between ideology, pragmatism and power relations.

\section{Conclusion}

The contention of this paper was that SURPs in the three Anglo-Saxon economies stimulated extant but diffuse EA-U as a form of employer counter-mobilisation in a number of ways. At first sight, the evidence presented for Britain and Eire seems to support the contention, with the outcome of EA-U varying in specific context and degree but not in kind. Yet because this was demonstrated in an overall, suggestive manner, with only implied (rather than demonstrated) cause and effect, this deduction must necessarily remain a tentative one. Moreover, the limited timeframes for the study of 
Britain and Eire, in comparison to the US, heighten this degree of tentativeness further. Notwithstanding the separate and different genesis of the US SURP, the case of the US here is interesting. First, it can be taken to give support to a more sophisticated version of the contention where temporal and situational factors are allowed to play their appropriate part. Second, there is continuing debate over which social and political forces led - and supported - the 'New Deal' reforms (including its SURP) and why. Swenson $(2002,2004)$ argued in favour of analysis based on a particular alignment of dominant cross-class forces coming together in a specific moment in time and for specific reasons. This is applicable to both Britain and Eire in as much as the creation of SURPs also represented the temporal and situational coming together of certain social forces to collectively exert their will in the form of a compromise outcome, rather than one group holding a proverbial gun to the head of another to enforce its will. The added salience of Swenson's analysis is that he also differentiated between varying segments of employers by interests and preferences on a relatively contingent basis to show that dissimilar responses existed to aspects of the 'New Deal'. Taking this notion of segmentation and applying it to the SURPs of Britain, Eire and the US, it is apparent that either not all non-union employers are predisposed to EA-U or that not all non-union employers are preordained to engage in EA-U. Indeed, the point is emphasised by the issue of the self-selecting nature of the deployed data where population samples which would have been able to show the relative proportions of different types of nonunion employer responses like acceptance as well as resistance - could not be constructed. But it remains the case that there is sufficient support for the contention of 
this paper to warrant further research into the specific nature of the environmental context and order of causation between the creation of a SURP and change in behaviour of a sizeable number of non-union employers. This would form part of developing a better explanation of why informs non-union employers to act in different ways as well as why there are majority and minority employer responses.

\section{References}

Abelow, R. (1958) 'Management experience under the Taft-Hartley Act' Industrial and Labor Relations Review, 11/3:360-370.

Adams, R. (1999) 'Why statutory union recognition is bad labour policy: the North American experience' Industrial Relations Journal, 30/2:96-100.

American Rights at Work (2006) 'Every 23 minutes/About this statistic' American Rights at Work leaflet and website <www.americanrightsatwork.org>.

Batstone, E. (1988) 'The frontier of control' in Gallie, D. (ed.) Employment in Britain, Blackwell, Oxford, pp218-247.

Bernstein, I. (1960) The Lean Years: a history of the American worker, 1920-1933, Houghton-Mifflin, Boston.

Bernstein, I. (1970) The Turbulent Years: a history of the American worker, 1933-1941, Houghton-Mifflin, Boston.

Bronfenbrenner, K. and Juravich, T. (1998) 'It takes more than house calls: organizing to win with a comprehensive union-building strategy' in Bronfenbrenner, K., Friedman, S., Hurd, R., Oswald, R and Seeber, R. (eds.) Organizing to Win: new research on union strategies, Cornell University Press, Ithaca, pp19-36.

Clawson, D. (2003) The Next Upsurge: labor and the new social movements, ILR Press, Ithaca, NY.

Clawson, D. and Clawson, M. (1999) 'What has happened to the US labor movement? Union decline and renewal' Annual Review of Sociology, 25:95-199.

Cohen, J. and Cohen, L. (1948) 'The National Labor Relations Board in retrospect' Industrial and Labor Relations Review, 1/4:648-656.

Cooke, W. (1983) 'Determinants of the outcomes of union certification elections' Industrial and Labor Relations Review, 36/3:402-414.

Cooke, W. (1985a) 'The failure to negotiate first contracts: Determinants and policy implications' Industrial and Labor Relations Review, 38/2:163-178.

Cooke, W. (1985b) 'The rising toll of discrimination against union activists' Industrial Relations, 24/3:421-42.

Cooke, W. (2001) 'Union avoidance and foreign direct investment in the USA' Employee Relations, 23/6:558-580. 
Cully, M., Woodland, S., O'Reilly, A. and Dix, G. (1999) Britain at Work - as depicted by the 1998 Workplace Employee Relations Survey, Routledge, London.

D'Art, D. and Turner, T. (1999) 'An attitudinal revolution in Irish industrial relations: the end of 'them' and 'us" British Journal of Industrial Relations, 37/1:101-116.

D'Art, D. and Turner, T. (2003) 'Union recognition in Ireland: one step forward or two steps back?' Industrial Relations Journal, 34/3:226-240.

D'Art, D. and Turner, T. (2005) 'Union recognition and partnership at work: a new legitimacy for Irish labour unions' Industrial Relations Journal, 36/2:121-139.

Dickens, W. (1983) 'The effect of company campaigns on certification elections: Law and Reality once again' Industrial and Labor Relations Review, 36/4:560-575.

Dubofsky, M. (1994) The State and Labour in Modern America, University of North Carolina Press, Chapel Hill, NC.

EIRO (2002) 'Ireland: Effectiveness of 'right to bargain' law questioned' Eironline, Dublin. EIRO (2005) 'Ireland: Union density declines to around a third' Eironline, Dublin.

EIRO (2007) 'Ireland: Unionised multinationals reject unions in new plants' Eironline, Dublin.

Ewing, K., Moore, S. and Wood, S. (2003) Unfair Labour Practices: labour union recognition and employer resistance, Institute of Employment Rights, London.

Farber, H. and Krueger, A. (1993) 'Union membership in the United States: the decline continues' in Kaufamn, B. and Kleiner, M. (eds.) Employee Representation: alternatives and future direction, IRRA, Madison, WI, pp105-134.

Fiorito, J. (2001) 'Human resource management practices and worker desires for union representation' Journal of Labor Research, 22/2:335-354.

Fiorito, J. (2002) 'Human resource management practices and desires for union representation' in Bennett, J. and Kaufman, B. (eds.) The Future of Private Sector Unionism in the United States, M.E. Sharp, Armonk, pp28-58.

Fiorito, J. (2003) 'Union organizing in the United States' in Gall, G. (ed.) Union

Organising: campaigning for trade union recognition, Routledge, pp191-210.

Flanagan, R. (2005) 'Has management strangled US unions?' Journal of Labor Research, 26/1:33-63.

Flood, P. and Toner, B. (1997) 'Large non-union companies: how do they avoid a Catch 22?' British Journal of Industrial Relations 35/2:257-277.

Freeman, R. (1986) 'Why are union faring poorly in NLRB representation elections?' in Kochan, T. (ed.) Challenges and Choices Facing American Labor, MIT Press, Cambridge, MA, pp45-64

Freeman, R. and Kleiner, M. (1990) 'Employer behavior in the face of union organizing drives' Industrial and Labor Relations Review, 43/4: 351-365.

Freeman, R. and Medoff, H. (1984) What Do Unions Do? Basic Books, New York.

Fulmer, W. (1982) Union Organizing: management and labor conflict, Praeger, New York.

Gall, G. (1993) 'Trade union strikes for union recognition, 1980-1990' Unpublished paper, University of Stirling, Stirling.

Gall, G. (2003) 'Introduction' in Union Organising: campaigning for labour union recognition, in Gall, G. (ed.), Routledge, pp1-18. 
Gall, G. (2004a) 'Trade union recognition in Britain, 1995-2002: turning a corner?' Industrial Relations Journal, 35/3:249-270.

Gall, G. (2004b) 'British employer resistance to trade union recognition' Human Resource Management Journal, 14/2:36-53.

Gall, G. (2007) 'Trade union recognition in Britain: a crisis of union capacity?' Economic and Industrial Democracy, 28/1:83-114.

Gall, G and McKay, S. (1994) 'Trade union derecognition in Britain 1988-1994' British Journal of Industrial Relations, 32/3:433-448.

Gould, W. (1994) Agenda for Reform: the future of employment relationships and the law, MIT Press, Cambridge, MA.

Gross, J. (1974) The Making of the National Labor Relations Board: A study in economics, politics, and the law (Volume 1, 1933-1937), State University of New York Press, Albany. Gross, J. (1981) The Reshaping of the National Labor Relations Board: National labor policy in transition, 1937-1947, State University of New York Press, Albany.

Gross, J. (1985) 'Conflicting statutory purposes: Another look at fifty years of NLRB law making' Industrial and Labor Relations Review, 39/1:7-18.

Gross, J. (1995) Broken promise: the subversion of US labor relations policy, 1947-1994, Temple University Press, Philadelphia.

Gunnigle, P., Collings, D. and Morley, M.J. (2006) 'Accommodating global capitalism? State policy and industrial relations in American MNCs in Ireland' Ferner, A., Quintanilla, J. and Sanchez-Runde, C. (eds.) Multinationals and the Construction of Transnational Practices: Convergence and Diversity in the Global Economy, Palgrave, Basingstoke, pp86-108.

Gunnigle, P., MacCurtain, S. and Morley, M. (2001) 'Dismantling pluralism; industrial relations in Irish greenfield sites' Personnel Review 30/3:263-279.

Gunnigle, P. and O'Sullivan, M. (2003) 'Organised labour in the Celtic Tiger: trends in labour union penetration in the Republic or Ireland' Unpublished paper, University of Limerick.

Gunnigle, P., O'Sullivan, M. and Kinsella, M. (2002) 'Organised labour in the new economy; labour unions and public policy in the Republic of Ireland' in Turner, T. and D'Art, D. (eds.) Irish Employment Relations and the New Economy, Blackhall, Dublin, pp222-258.

Heery, E. (2000) 'New unionism research project' Bulletin No. 8, Cardiff University, Cardiff.

Heery, E. and Simms, M. (2003) Bargain or Bust? Employer responses to union organising, TUC, London.

Heery, E. and Simms, M. (2006) 'Union organising under certification law in Britain' in Gall, G. (ed.) Union Recognition; organising and bargaining outcomes, Routledge, London, pp44-63.

Heery, E., Simms, M., Simpson, D., Delbridge, R., and Salmon, J. (2000a). 'Organising unionism comes to Britain' Employee Relations, 22/1:38-57.

Jordan, L. and Bruno, B. (2006) 'Does the organising means determine the bargaining ends?' in Gall, G. (ed.) Union Recognition; organising and bargaining outcomes, Routledge, London, pp181-197. 
Keoller, C. (1992) 'Employer unfair labor practices and union organizing activity: a simultaneous equation model' Journal of Labor Research, 13/2:173-187.

Kersley, B., Alpin, C., Forth, J., Bryson, A., Bewley, H., Dix, G., and Oxenbridge, S. (2005) Inside the Workplace: first findings from the 2004 Workplace Employment Relations Survey, DTI, London.

Kersley, B. Alpin, C. Forth, J. Bryson, A. Bewley, H. Dix, G. and Oxenbridge, S. (2006) Inside the Workplace: findings from the 2004 Workplace Employment Relations Survey, Routledge, London.

Klein, J. and Wanger, E. (1986) 'The legal setting for the emergence of the union avoidance strategy' in Kochan, T. (ed.) Challenges and Choices Facing American Labor, MIT Press, Cambridge, MA, pp75-88.

Kleiner, M. (1984) 'Unionism and employer discrimination: analysis of 8(a)(3) violations' Industrial Relations, 23/2:234-243.

Kleiner, M. (2001) 'Intensity of management resistance: understanding the decline of unionization in the private sector' Journal of Labor Research, 22/3:519-540.

Kochan, T. (1980) Collective bargaining and industrial relations, Richard Irwin, Homewood, III.

Kochan, T., Katz, H. and McKersie, T. (1984) The Transformation of American Industrial Relations, Basic Books, New York.

Labour Court (1992-2007) Annual Report, Labour Court, Dublin, available at $<$ www.labourcourt.ie>.

Lipset, S. and Katchanovski, I. (2001) 'The future of private sector unions in the US' Journal of Labor Research, 22/2:229-244.

Logan, J. (2001) 'Is statutory recognition bad news for British unions? Evidence for the history of North American industrial relations' Historical Studies in Industrial Relations, 11:63-107.

Logan, J. (2002) 'Consultants, lawyers and the 'union free' movement in the USA since the 1970s' Industrial Relations Journal, 33/3:197-214.

McCammon, H. (2001) 'Labor's legal mobilization: why and when do worker file unfair labor practices?' Work and Occupations, 28/2:143-175.

McDonald, C. (1986) 'Discussion Part 1' in Kochan, T. (ed.) Challenges and Choices Facing American Labor, MIT Press, Cambridge, MA, pp45-64.

McGovern, P. (1989) 'Union recognition and union avoidance in the 1980s' in Murphy, T. (ed.) Industrial Relations in Ireland: contemporary trends and developments, UCD, Dublin, pp61-72.

Mercer, S. and Notley, R. (2008) Trade Union Membership 2007, Department of Business, Enterprise and Regulatory Reform/National Statistics, London.

Meyer, D. and Cooke, W. (1993) 'US labour relations in transition: emerging strategies and company performance' British Journal of Industrial Relations, 31/4:531-552.

Millward, N., Bryson, A. and Forth, J. (2000) All Change at Work? British employment relations 1980-1998, as portrayed by the Workplace Industrial Relations Survey series, Routledge, London.

Moody, K. (1986) An Injury to All: the decline of American unionism, Verso, London. 
Moody, K. (2007) US Labor in Trouble and Transition - the failure of reform from above, the promise of revival from below, Verso, London.

Moore, S. (2004) 'Union mobilization and employer counter-mobilization in the statutory recognition process' in Kelly, J. and Willman, P. (eds.) Union Organization and Activity, Routledge, London, pp7-31.

Pavy, G. (1994) 'Winning NLRB elections and establishing collective bargaining relationships' in Friedman, S., Hurd, R., Oswald, R. and Seeber, R. (eds.) Restoring the promise of American labor law, pp110-121.

Renshaw, P. (1991) American Labour and Consensus Capitalism 1935-1990, Macmillan, Baskingstoke.

Roche, W. (1998) 'The problem of trade union recognition: endangering social consensus in Ireland?' European Industrial Relations Observatory, EIROnline, (IE9803114F).

Roche, W. (2001) 'Accounting for the trend in labour union recognition in Ireland' Industrial Relations Journal 32/1:37-54

Roomkin, M. (1981) 'A quantitative study of unfair labour practice cases' Industrial and Labor Relations Review, 34/2:245-256.

Seeber, R. and Cooke, W. (1983) 'The decline in union success in NLRB representation elections' Industrial Relations, 22/1:34-44.

Smith, P. and Morton, G. (2001) 'New Labour's reform of Britain's employment law: The devil is not only in the detail but in the values and policy too' British Journal of Industrial Relations, 39/1: 119-138.

Snape, E. (1994) 'Union organizing in Britain: the views of local full-time officials' Employee Relations, 16/8:48-62.

Swenson, P. (2002) Capitalists against Markets: the making of labor markets and welfare states in the United States and Sweden, Oxford University Press, New York.

Swenson, P. (2004) 'Varieties of capitalist interests: power, institutions, and the regulatory welfare state in the United States and Sweden' Studies in American Political Development, 18/1:1-29.

Towers, B. (1999) '... the most lightly regulated labour market ... Britain's third statutory union recognition procedure' Industrial Relations Journal, 30/2:82-95.

Towers, B. (2003) 'Comparisons and prospects: industrial relations and labour unions in North America and Britain' in Gall, G. (ed) Union Organizing: campaigning for labour union recognition, Routledge, London, pp.173-190.

Turner, T. D'Art, D. and Gunnigle, P. (1997) 'Pluralism in retreat? A comparison of Irish and multinational manufacturing companies' International Journal of Human Resource Management, 8/6:835-840.

Zeiger, R. (1997) The CIO, 1935-1955, University of North Carolina Press, Chapel Hill, CA. 